\title{
STUDIES ON THE CELL-MEDIATED IMMUNITY IN CHICKENS INFECTED WITH MAREK'S DISEASE VIRUS
}

\author{
V. BENDA \\ Institute of Molecular Genetics, Czechoslovak Academy of Sciences, 16610 Prague
}

Received August 8, 1978

\begin{abstract}
Benda V.: Studies on the Cell-Mediated Immunity in Chickens Infected with Marek's Disease Virus. Acta vet. Brno, 47, 1978: 197-201.

The effect of lymphocytes from MDV-infected chickens on ${ }^{51} \mathrm{Cr}$-labelled HPRS line 1 lymphoblasts derived from an from an MDV-induced lymphoma was investigated by using a cytotoxicity test (CTT). In comparison with the control and vaccinated chickens, chickens inoculated with MDV showed cytotoxic activity as long as 11 weeks after infection. This supports the view of an important role of the cell-mediated immunity in the pathogenesis of Marek's disease.
\end{abstract}

${ }^{51} \mathrm{Cr}$ cytotoxic assay, turkey herpesvirus.

Marek's disease (MD), a herpesvirus-caused lymphoproliferative disease of chickens (Chur chill and Biggs 1967), is not only an economically important zoonosis, but also a suitable experimental model for studying the pathogenesis of the virus-induced tumour diseases. Attention has been directed recently towards the mechanism of natural and vaccine-induced immune response of chickens against infection with the oncogenic Marek's disease virus (MDV), perhaps in connection with the data reported on variations in the reliability of MDV vaccines. The cell-mediated reaction, more precisely, the reaction mediated by sensitized $T$ lymphocytes, which tends to eliminate cells bearing MDV-specific virus antigens of MD-specific tumor antigens, the latter being designated MATSA (Witt er et al. 1975), is presumed to predominate in this case. This comunication presents some findings supporting the assumption that an antitumour immunity exists in MDV-infected chickens.

\section{Materials and Methods}

\section{Chickens}

Leukosis-free Rhode Island Red chickens (Biggs et al. 1968), which are susceptible to MD (experiment A), and chickens of the inbred line WA (Hála et al. 1966) (experiment B), both from the Institute's own flock, were maintained under conventional conditions, each group kept in separate room. The sacrificed and dead chickens were examined for the presence of MD lymphomas.

\section{Viruses}

MDV, strain GA of acute MD virus (Eidson and Schmittle 1968), was propagated in susceptible chickens, and infection was performed by intraperitoneal injection of heparinized blood. The FC-126 strain of herpesvirus of turkeys (HVT), used for vaccine preparation (Wit ter et al. 1970), was propagated and inoculated in chicken embryo fibroblasts.

The HPRS line 1 lymphoblasts, originally derived from an MDV-induced ovarian lymphoma (Powell et al. 1974), were kindly provided by Dr. P. C. Powell, Houghton Poultry Research Station, England, in 1976 and have since been cultured in suspension in this laboratory. This line consists almost exclusively of T cells which bear a MATSA on their surface in $90 \%$ (Matsuda et al. 1976). 


\section{Cytotoxicity test (CT'T)}

The cytotoxicity assay with ${ }^{51} \mathrm{Cr}$ labelling of target cells was carried out essentially as described previously (Powell 1976; Sharma and Coulson 1977). $2 \times 10^{7}$ HPRS line 1 target cells were thawed and suspended in $4 \mathrm{ml}$ of RPMI 1640 medium containing $20 \%$ calf serum and labelled with $100 \mu \mathrm{Ci} \mathrm{Na}{ }_{2}{ }^{51} \mathrm{CrO}_{4}$ (Radiochemical Centre, Amersham, Bucks., England), spec. act. 100 to $400 \mathrm{mCi} / \mathrm{mg} \mathrm{Cr}$ at $37^{\circ} \mathrm{C}$ for $60 \mathrm{~min}$. After labelling, the cells were washed and mixed with the effector cells, i. e., peripheral blood lymphocytes, separated from heparinized blood by differential centrifugation in a Verografin solution (Spofa, Prague) (Benda and Hložánek 1976), at an effector: target cell ratio of $50: 1$. After centrifugation, the cell mixture was incubated at $37^{\circ} \mathrm{C}$ in tubes either for $4 \mathrm{hr}$ with shaking the cells on a shaker (experiment A) or for $18 \mathrm{hr}$ in the stationary phase (experiment B). The per cent cytotoxicity was expressed as:

$$
\frac{\text { Experimental release of }{ }^{51} \mathrm{Cr}}{{ }^{51} \mathrm{Cr} \text { total incorporated }} \times 100
$$

Each value is the mean of 9 measurements in 3 chickens.

Differences between groups were statistically evaluated by the Student t-test.

\section{Experimental design}

In experiment A, blood samples to be used in CTT were collected 3 and 6 weeks after infection and vaccination, respectively, of chickens that had been infected with MDV at 1 or 21 days of age and chickens that had been inoculated with 1.900 plaque-forming units (PFU) of HVT at 1 day of age. The values obtained were compared with those of the control chickens of the same age as were the vaccinated chickens and chickens infected when 1 day old. Experiment B was done in the same manner with WA-line chickens that had been vaccinated with 960 PFU of HVT at 1 day of age, the infected group received $M D V$ as late as 21 days of age, and blood samples were collected only once, at 77 days of age.

\section{Results}

The results obtained in experiment A (Tab. 1) show that CTT in the immune response under investigation was significantly increased as early as 3 weeks after infection in the group of chickens that had been infected with MDV when

Table 1

Cytotoxic response in Rhode Island Red chickens (experiment A)

\begin{tabular}{|c|c|c|c|c|c|}
\hline Group & Virus & $\begin{array}{c}\text { Age at virus } \\
\text { infection } \\
\text { (days) }\end{array}$ & $\begin{array}{c}\text { Incidence } \\
\text { of MD } \\
(\%)\end{array}$ & \multicolumn{2}{|c|}{$\begin{array}{c}\text { \% CTT response } \\
\text { (days postinfection) }\end{array}$} \\
\hline & MDV & 1 & 66 & 21 & 42 \\
\hline 2 & HVT & 1 & 0 & $24.3 * * *$ & $34.6 * * *$ \\
3 & MDV & 21 & 27 & 23.2 & 21.3 \\
Controls & - & - & 0 & 20.8 & 29.7 \\
\hline
\end{tabular}

$* * *-P<0.001$.

1 day old (group 1), compared to the control $(P<0.001)$ and vaccinated chickens (group 2) $(P<0.002)$ of the same age. The difference between group 1 (chickens infected after hatching) and the controls was highly significant even at 6 weeks postinfection $(P<0.001)$. The values in further experimental groups 2 and 3 , still markedly differed $(P<0.001$ and $P<0.005$, respectively), from those in group 1, but per cent cytotoxicity of lymphocytes from these chickens declined below the values of the control group. Similar, though less singificant, differences were found in experiment $B$, where the infected and vaccinated groups differed 
Table 2

Cytotoxic response in WA-line chickens (experiment B)

\begin{tabular}{|l|c|c|c|}
\hline \multicolumn{1}{|c|}{ Virus } & $\begin{array}{c}\text { Age at virus infection } \\
\text { (days) }\end{array}$ & $\begin{array}{c}\text { Incidence of MD } \\
\text { (\%) }\end{array}$ & $\begin{array}{c}\text { \% CTT response } \\
\text { (at 77 days of age) }\end{array}$ \\
\hline MDV & 21 & 27.3 & $\begin{array}{c}87.4^{* *} \\
\text { HVT } \\
\text { Controls }\end{array}$ \\
\hline
\end{tabular}

** $-P<0.005$.

from each other $(P<0.02)$ in their response and both differed from the control chickens $(P<0.005)$ (Tab. 2). Specific mortality from MD in both experiments corresponded to the virus used and the age at which chickens were infected.

\section{Discussion}

Although the interaction between MDV-sensitized and MVD-transformed T lymphocytes is considered to be the key mechanism of antitumor immunity in MD (Sharma 1977), experimental works investigating this problem by means of CTT are not numerous and the results obtained are contradictory in part. In our experiments, as in those of Powell (1976), a demonstrable CTT reation occurred 3 weeks postinfection and persisted for an another 8 weeks when compared with that in the control and vaccinated chickens. In birds infected at a later interval (on day 21), the antitumour immune response developed more slowly and was accompanied by lower specific mortality, most probably owing to the resistance to MD increasing with age (Sevoian and Chamberlain 1963). In our experiments, which were not performed in isolators, the possible infection by the apathogenic strains of MDV could not be excluded; it could have caused, for example, the strong CTT reaction in 6-week-old controls. Different results were reported by Sharma and Couls on (1977), who, however, used cells of the MSB-1 line as the targer cells (Akiyama and Kato 1974). They detected a CTT response for only 4 weeks after infection, but suggested that there is a close relationship between an immune response and the appearance of lymphoproliferative lesions characteristic of $\mathrm{MD}$. In further exepriments Sharma (1977) demonstrated that the CTT response in MD was mediated mainly by $\mathrm{T}$ cells, when it was inhibited by treating the effector cells with antithymocyte serum. It should be admitted that the CTT values obtained in our experiments, as those reported in the experiments quoted above, were not quite significant. A comparison of the specific and spontaneous release of the isotope revealed that a shorter incubation time, the 4 -hr period used in experiment $\mathrm{A}$, seems more appropriate for highly susceptible HPRS line 1 cells. The CTT may be unfavourably influenced by the histocompatibility differences between effector and target cells (Sharma 1977), in addition to the technical problems. The low intensity of CTT response in MDV-infected chickens attracts attention to the thus far neglected component of the cell-mediated response directed against virus-specific antigens, which induced $M D V$ in the infected cells. An elegant demonstration of this reaction has been provided by Ross (1977) in an in vitro system. Many investigators (Powell and Rowell 1977; Kaaden 1977), therefore assume that an antitumour immunity in $M D$ induced by vaccination is mostly directed agains virus-specific antigens, in spite of the presence of MATSA 
even in the vaccinated birds as described recently by Powell and Rennie (1978), whereas both the antitumour and anti-virus components are involved in natural immunity. Nevertheless, some relation between both types of these antigens, or the existence of other, thus far unidentified antigens, cannot be excluded (Ross 1977; Powell and Rowel 1977).

\section{Sledování buňkami zprostředkované imunity u kư̆at infikovaných virem Markovy nemoci}

S pomocí cytotoxického testu (CTT) byl sledován účinek lymfocytů virem Markovy nemoci (MDV) infikovaných kuřat na ${ }^{51} \mathrm{Cr}$ značené buňky lymfoblastoidní linie HPRS 1 odvozené z MDV indukovaného lymfómu. Ve srovnání s kontrolními i vakcinovanými kuřaty bylo možno prokázat cytotoxickou aktivitu ještě 11 týdnů po infekci MDV, což podporuje názor o významné úloze imunity v patogeneze Markovy nemoci.

\section{Изучение клеточного иммунитета у цыплят зараженных вирусом болезни Марека}

Исследовали влияние лимфоцитов цыплят зараженных вирусом болезни Марека (MDV) на ${ }^{51} \mathrm{Cr}$ меченные клетки лимфобластоидной линии HPRS 1 из лимфомы индуцированной вирусом болезни Марека с помощью цитотоксического теста. Цыплята зараженные MDV, по сравнению с контрольными и вакцинированными цыплятами, оказывали цитотоксическую активность через 11 недель после заражения MDV. Это поддерживает гипотезу об особо важной роли обосредованного клетками иммунитета в патогенезе болезни Марека.

Корреляционные отношения кальция и фосфора, установленные у контрольной группы, у БМ положительных цыплят не подтвердились и другие не наблюдались.

Наличие болезни Марека в случае подопытных цылят РИР отличалось чаще всего имеющим место опухольным заболеванием почек, печени и селезенки за счет пострадация гонад по сравнению с описываемыми свойствами других штаммов с острой формой болезни Марека.

\section{References}

AKIYAMA, Y. - KATO, S.: Two cell lines from lymphoma of Marek's disease. Biken J., 17, 1974: $105-116$.

BENDA, V. - HLOŽÁNEK, I.: Virus-neutralization test as a possible indicator of vaccination against Marek's disease. Acta vet. Brno, 45, 1976: 117-121.

BIGGS, P. M. - THORPE, R. J. - PAYNE, L. N.: Studies on genetic resistance to Marek's disease in the domestic chickens. Brit. Poultry Sci., 9, 1968: 37-52.

CHURCHILL, A. E. - BIGGS, P. M.: Agent of Marek's disease in tissue culture. Nature, 215, 1967: 528-530.

EIDSON, C. S. - SCHMITTLE, S. C.: Studies on acute Marek's disease I. Characteristics of isolate GA in chickens. Avian Dis., 12, 1968: 467-476.

HÁLA, K. - HAŠEK, M. - HLOŽÁNEK, I. - HORT, J. - KNÍŽETOVÁ, F. - MERVARTOVÁ, H.: Syngeneic lines of chickens. II. Inbreeding and selection within the $M, W$, and $I$ lines and crosses between the $C, M$ and Wlines. Fol. Biol. (Praha), 12, 1966: 407-422.

KAADEN, O. R.: Marek's disease virus-induced antigens in relation to immunity. Avian Pathol., 6, 1977: 219-225. 
MATSUDA, H. - IKUTA, K. - MIYAMOTO, H. - KATO, S.: Demonstration of Marek's disease tumor-associated surface antigen (MATSA) on six cell lines derived from Marek's disease lymphomas. Biken J., 19, 1976: 119-123.

POWELL, P. C.: Studies on Marek's disease lymphoma derived cell lines. Bibl. Haemat., 43, 1976: $348-350$.

POWELL, P. C. - PAYNE, L. N. - FRAZIER, J. A. - RENNIE, M.: T lymphoblastoid cell lines from Marek's disease lymphomas. Nature, 251, 1974: 79-80.

POWELL, P. C. - RENNIE, M.: Marek's disease tumour-specific antigen (MATSA) induced by the herpesvirus of turkeys (HVT) in vaccinated chickens. Vet. Rec., in press.

POWELL, P. C. - ROWELL, J. G.: Dissociation of antiviral and antitumor immunity in resistance to Marek's disease. J. Natl. Cancer Inst., 59, 1977: 919-924.

KOSS, L. J. N.: Antiviral T cell-mediated immunity in Marek's disease. Nature, 268, 1977: $644-646$.

SEVOIAN, M. - CHAMBERLAIN, D. M.: Avian lymphomatosis. III. Incidence and manifestations in experimentally infected chickens of various ages. Avian Dis., 7, 1963: 97-102.

SHARMA, J. M.: Cell-mediated immunity to tumor antigen in Marek's disease: Susceptibility of effector cells to antithymocyte serum and enhancement of cytotoxic activity by Vibrio cholerae neuraminidase. Infect. Immun., 18, 1977; 46-51.

SHARMA, J. M. - COULSON, B. D.: Cell-mediated cytotoxic response to cells bearing Marek's disease tumor-associated surface antigen in chickens infected with Marek's disease virus. J. Natl. Cancer Inst., 58, 1977: 1647-1651.

WITTER, R. L. - NAZERIAN, K. - PURCHASE, H. G. - BURGOYNE, G. H.: Isolation from turkeys of a cell-associated herpesvirus antigenically related to Marek's disease virus. Am. J. Vet. Res., 31, 1970: 525-538.

WITTER, R. L. - STEPHENS, E. A. - SHARMA, J. M. - NAZERIAN, K.: Demonstration of a tumor-associated surface antigen in Marek's disease. J. Immunol., 115, 1975: $177-183$. 